\title{
Medical ethics: a brief response to Seedhouse
}

\author{
Peter Toon Medical Colleges of the Royal London and St Bartholomew's Hospital, London
}

\begin{abstract}
Medical ethics is that branch of applied philosophy which considers issues of values raised by medical practice, and should not be equated with 'principlism'. Clarification of facts/values distinctions is an important part of this work. The notion that medical philosophy can flourish in the hands of medical 'generalists' without specialist philosophers, is misguided. Both must work together to promote right reason and right action in medical education and practice.
\end{abstract}

It is ironic that a general practitioner should be defending the role of ethicists in the medical establishment against a philosopher who is a senior lecturer in medical ethics! My short article on virtue ethics in medicine was not an attack on Seedhouse, so I do not see his need for a 'response', particularly as much of what he says in his response seems to support rather than oppose my argument.

I still do not understand what sort of being Seedhouse's 'generalists' would be, if not as I assumed wise physicians who merely included some knowledge of moral philosophy amongst their many clinical skills. My experience of medical education, both by generalists and specialists is considerably wider than Seedhouse suspects. As a generalist myself, and a medical teacher, I am fully aware of the value of such individuals and the need for them to play a greater part in medical education. I am, however, also conscious of the complementary value of specialists, including specialists in moral philosophy. It is unlikely that satisfactory theory can be applied and tested with any rigour without a body of people whose main job is the study of that discipline and not the treatment of patients. Holders of posts in health philosophy, health care history and medical law would be as much specialists as cardiologists or renal physicians.

If as he said in his editorial (1) he thinks that 'medical ethics can have no special area of study' and 'ethics experts ... must refuse to teach medical

\section{Key words}

Philosophy of medicine; teaching medical ethics. ethics at all ... or make themselves redundant as ethicists as soon as possible' to say that 'medical ethics should cease to exist as soon as possible' seems to me a reasonable summary of that position.

I would agree wholeheartedly that there tends to be an overemphasis on the exceptional and the dramatic in medical ethics - as there is in other areas of medical research. I have criticised this, and in my own research tried to concentrate on the common rather than the spectacular.

I cannot, however, see why he contrasts medical ethics with philosophy of medicine. Surely ethics is that part of philosophy which deals with moral values and moral aspects of actions? Medical ethics is therefore part of medical philosophy, a wider field also including the philosophical study of other issues relevant to medical practice, notably epistemology and philosophy of mind. This subdivision of philosophy is not 'parasitic' on moral philosophy, but is the application of an intellectual discipline to a particular range of problems. Such applications generate new hypotheses and test theories. The relationship is better described as symbiosis than parasitism.

His belief that no distinction can be drawn between the ethical and empirical aspect of medicine is both wrong and dangerous. Whether or not there is a fundamental metaphysical distinction between facts and values, in clinical practice one can and must distinguish the two dimensions, which Seedhouse rightly states are present in any clinical issue (2). Failure to do so results in muddled thinking. Hume's naturalistic fallacy (3) is rife in medicine. Seedhouse's argument encourages the powerful body of opinion which believes that medical ethics is just a matter of opinion, or 'what good chaps do', not capable of being studied and analyzed with the same intellectual rigour as empirical questions.

Seedhouse is, however, I think mistaken to equate medical ethics with 'principlism'. There is now a wide consensus that approaches not rooted in a coherent metaethic are unsatisfactory. As Macintyre (4) demonstrates, this problem is not unique to medicine. My purpose was not to dispute with the internal critics of medical ethics, but to argue that we need both the intellectual study of 
what it is right to do, and the study of how we ensure that right actions are actually taken Aquinas's (5) 'right reason' and 'habit of acting rightly'. This will require not the redundancy of medical ethicists but their proliferation, working alongside clinicians in departments of medical philosophy within medical schools. If these are called departments of medical ethics rather than of health philosophy this is a small price to pay for their major role in strengthening medical education.

Peter D Toon is an Honorary Lecturer in the foint Department of Human Sciences and Medical Ethics at the Medical Colleges of the Royal London and St Bartholomew's Hospital, Turner Street, London, E1.

\section{References and notes}

(1) Seedhouse D. Against medical ethics; a philosopher' view. Medical education 1991; 25, 2: 280-282.

(2) Toon P D. Defining disease - classification must bह distinguished from evaluation. Fournal of medical ethics. 1981; 7: 197-202.

(3) Hume D. In: Selby-Bigge L A, ed. A treatise of humat nature. Oxford: Clarendon, 1984: 269.

(4) MacIntyre A. After virtue [2nd ed]. London Duckworth, 1985.

(5) Aquinas, in the Summa theologiae gives various definitions of virtue, all similar in intent. These phrasess are crucial to the one which Gilson E, Le Thomisme Paris, Libraire Philosophique, 1972 refers to a 'la notion de vertue sous sa forme la plus parfaite' and which can be found at Ia IIae 64, 1 .

\section{News and notes}

\section{Norwegian ban on embryo research remains}

Under the new Norwegian Act relating to the application of biotechnology in medicine, research on embryos remains banned: use of insemination by donor in combination with in vitro fertilisation is also forbidden.
The Norwegian parliament (the Storting) prohibited egg donation in 1993.

Parliament decided the Act should be reviewed in 1999.

\section{News and notes}

\section{Sixth International Congress on Ethics in Medicine}

The Sixth International Congress on Ethics in Medicine will be held in New York City from 22 to 25 October, 1995. For details write to: Beth Israel Medical Center,
Department of Ethics in Medicine, 1st Avenue at 16th Street, New York NY1003. 